\title{
One day descriptive study of quality of life in headache cases
}

\author{
Rajesh Kunwer ${ }^{1}$, Vishal Singh ${ }^{2}$, Anuj Kumar Tripathi ${ }^{3 *}$, Saurabh Pathak ${ }^{4}$, O P Gupta \\ ${ }^{1}$ Associate Professor, ${ }^{2}$ Data Analyst and Statistician, ${ }^{3}$ Assistant Professor, ${ }^{4,5}$ Professor, ${ }^{1}$ Dept. of Anaesthesia,,${ }^{3,45}$ Dept. of General \\ Surgery, Career Institute of Medical Sciences \& Hospital, Lucknow, Uttar Pradesh, India
}

*Corresponding Author: Anuj Kumar Tripathi

Email: dranujkumartripathi@gmail.com

\begin{abstract}
Headache, an almost universal human experience, is one of the most common complaints encountered in medicine and neurology. In recent years, there has been a lot of focus on the impact of both physical and mental illness in terms of their impact on quality of life. The idea of quality of life is undoubtedly a multidimensional concept, which emphasizes the self-perception of an individual's current state of mind. ${ }^{1}$ The quality of life scale is based on many things, including: Mental and physical well-being. Relationships with other people. Social, community, and civic activities. Personal development and fulfillment. Recreation and fun.
\end{abstract}

Keywords: Headache, Quality of life, Descriptive study.

\section{Introduction}

Ancient references to headache, migraine, and neuralgia can be found in the Ebers Papyrus (1200 B.C.) A primary headache has no known underlying cause. Secondary headache is the result of another condition causing traction on or inflammation of pain-sensitive structures. Headache due to psychiatric disease is also considered secondary. The most common primary headaches include migraine, tension-type headache, and cluster headache. Headaches related to infection, vascular disease, and trauma are examples of more common secondary headaches. Only $1 \%$ of patients with brain tumor will have headache as the sole complaint. ${ }^{2}$ Fortunately the vast majority of patients who present to their primary care provider for an evaluation will have a primary headache disorder.

\section{Materials and Methods}

In this study we included 568 cases of headache with normal computed tomography brain study. Age range was 18 years to 40 years. This study was descriptive in nature and outdoor basis. Others pathologies like hypertension, diabetes, tuberculosis, tobacco users etc. All cases were given a form which included following criteria's.

\section{Result}

Male and female ratio was 91:9

Table 1: The demographic profile of the patient

\begin{tabular}{|l|c|}
\hline Age group (Year) & Percentage \\
\hline 18 to 25 & $16 \%$ \\
\hline 26 to 32 & $22 \%$ \\
\hline 33 to 40 & $62 \%$ \\
\hline
\end{tabular}

Table 2: Intensity of headache in different age group

\begin{tabular}{|c|c|c|c|}
\hline \multirow{2}{*}{$\begin{array}{c}\text { Age group } \\
\text { (Year) }\end{array}$} & \multicolumn{3}{|c|}{ Intensity of Headache } \\
\cline { 2 - 4 } & Mild & Moderate & Severe \\
\hline 18 to 25 & $5(17.8 \%)$ & $21(75 \%)$ & $2(7 \%)$ \\
\hline 26 to 32 & $5(12.8 \%)$ & $9(23 \%)$ & $25(64 \%)$ \\
\hline 33 to 40 & $14(12.8 \%)$ & $27(24.7 \%)$ & $68(62 \%)$ \\
\hline
\end{tabular}

Headache is seen mostly in young age group predomintentely in female. The most common group involve in 26 to 40 years maximum in 33 to 40 years. It may because low socio economic status.

The quality of life scale is based on many things, including: Mental and physical well-being. Relationships with other people. Social, community, and civic activities. Personal development and fulfilment. Recreation and fun (Table 3).

\section{Table 3}

\begin{tabular}{|l|c|c|c|}
\hline \multirow{2}{*}{ Quality of life } & \multicolumn{3}{|c|}{ Outcome. } \\
\cline { 2 - 4 } & $\begin{array}{c}\text { Mild } \\
\text { headache }\end{array}$ & $\begin{array}{c}\text { Moderate } \\
\text { headache }\end{array}$ & $\begin{array}{c}\text { Severe } \\
\text { headache }\end{array}$ \\
\hline $\begin{array}{l}\text { Mental and } \\
\text { physical well- } \\
\text { being. }\end{array}$ & 310 & 168 & 90 \\
\hline $\begin{array}{l}\text { Relationships } \\
\text { with other people. }\end{array}$ & 213 & 133 & 122 \\
\hline $\begin{array}{l}\text { Social, } \\
\text { community, and } \\
\text { civic activities }\end{array}$ & 383 & 105 & 80 \\
\hline
\end{tabular}




\begin{tabular}{|l|c|c|c|}
\hline $\begin{array}{l}\text { Personal } \\
\text { development and } \\
\text { fulfilment }\end{array}$ & 158 & 207 & 203 \\
\hline $\begin{array}{l}\text { Recreation and } \\
\text { fun }\end{array}$ & 208 & 200 & 160 \\
\hline
\end{tabular}

\section{Review of Literature}

Headache is commonly seen in female with young age group and overall prevalence of headache is $96 \%$. The global active prevalence of tension-type headache is approximately $40 \%$ and migraine $10 \%$. Migraine occurs most commonly between the ages of 25 and 55 years and is 3 times more common in females ${ }^{3,4}$ same as our study. Despite the fact that it causes significant disability, headache remains underdiagnosed and undertreated. Chronic daily headache, daily or near-daily headache for months to years, is widely reported in the literature, yet is not an official diagnosis in the International Classification of Headache Disorders. Worldwide prevalence of chronic daily headache has been consistent at 3\%-5\% most of which likely represents chronic headache. Only $1 \%$ of patients with brain tumour will have headache as the sole complaint. ${ }^{5}$ There is no diagnostic test for headache, and evidence suggests that, in the specific setting of headache with a normal neurologic examination, imaging is overwhelmingly likely to be unremarkable. ${ }^{6,7}$

\section{Discussion}

The direct and indirect socioeconomic costs of headache to society are very high. Early and accurate diagnosis and appropriate treatment will help to reduce pain and suffering and the economic burden. Headache, a condition that has been described almost since the beginning of recorded history, is now an area of increasingly intense interest and focus. A flexible system of categorization of the various headaches allows for proper management in the present and sets the stage for advancement of future discoveries.

\section{Source of Funding}

None.

\section{Conflict of Interest}

None.

\section{References}

1. Bonomi AE, Patrick DL, Bushnel DM, Martin M. Quality of life measurement: will we ever be satisfied? J Clin Epidemiol. 2000;53(1):19-23.

2. Green MW. Secondary headaches. Continuum (Minneap Minn). 2012;18(4):783-95.

3. Robbins MS, Lipton RB. The epidemiology of primary headache disorders. Semin Neurol. 2010;30(2):107-19.

4. Stovner LJ, Hagen K, Jensen R. The global burden of headache: a documentation of headache prevalence and disability worldwide. Cephalalgia. 2007; 27:193-210

5. Green MW. Secondary headaches. Continuum (Minneap Minn). 2012;18(4):783-95.

6. Holle D, Obermann M. The role of neuroimaging in the diagnosis of headache disorders. Ther Adv Neurol Disord. 2013;6(6):369-74.

7. Tsushima Y, Endo K. MR imaging in the evaluation of chronic or recurrent headache. Radiol. 2005;235(2):575-9.

How to cite this article: Kunwer R, Singh V, Tripathi AK, Pathak S, Gupta OP. One day descriptive study of quality of life in headache cases. $J$ Community Health Manag. 2020;7(1):1-2. 